\title{
Pembelajaran Mitigasi Bencana Alam Gempa Bumi untuk Anak Usia Dini melalui Buku Bacaan Bergambar
}

\author{
Maila D.H. Rahiem ${ }^{{ }_{1}}$, Fira Widiastuti ${ }^{2}$ \\ Pendidikan Islam Anak Usia Dini, Universitas Islam Negeri Syarif Hidayatullah Jakarta \\ DOI: $\underline{10.31004 / o b s e s i . v 5 i 1.519}$
}

\begin{abstract}
Abstrak
Buku adalah salah satu media pembelajaran mitigasi bencana alam yang mudah diakses dan relatif murah. Pada penelitian ini, peneliti mengkaji bagaimana tampilan dan isi buku seri pengetahuan bencana alam yang berjudul "Aku Tahu Gempa Bumi." Penelitian menggunakan pendekatan kualitatif analisis buku dengan data tambahan berasal dari wawancara mendalam. Narasumber yang diwawancara adalah tiga orang guru dan tigaorangtua. Data penelitian menunjukkan bahwa: 1) buku tersebut memiliki gambar yang informatif dan menarik; (2) bahasa pada buku singkat, jelas dan mudah dipahami oleh anak; dan (3) buku memberi pengetahuan dan memotivasi anak untuk siaga bencana. Diharapkan lebih banyak lagi buku pembelajaran mitigasi bencana alam bagi anak usia dini yang berkualitas, menarik, menginspirasi dan yang dapat mempersiapkan anak-anak untuk sigap dan tangguh (resilient) dalam menghadapi bencana.
\end{abstract}

Kata Kunci: pendidikan mitigasi; bencana alam; anak usia dini

\begin{abstract}
The book is one of the readily available and reasonably inexpensive natural disaster mitigation learning media. In this study, researchers examined how the presentation and content of the natural disaster knowledge book, "I Know the Earthquake." The research used a qualitative approach to book review analysis, with additional data obtained from in-depth interviews. The interviewees included three teachers and three parents. Research data shows that: 1) the book contains informative and fascinating images; 2) the language in the book is simple, descriptive, and easily understood by children; and 3) the book provides information and inspire children to prepare for disasters. We hope that there will be more high-grade, informative, and empowering books on natural disaster mitigation for young children so that we can better educate them to be alert and resilient in the face of disasters.
\end{abstract}

Keywords: mitigation education; natural disasters; early childhood

Copyright (c) 2020 Maila D.H. Rahiem, Fira Widiastuti

$\triangle$ Corresponding author :

Email Address : mailadinia@uinjkt.ac.id (Jakarta, Indonesia)

Received 17 April 2020, Accepted 22 April 2020, Published 24 April 2020 


\section{PENDAHULUAN}

Bencana adalah bagian dari proses alam yang terjadi melebihi frekuensi biasanya dan menyebabkan "kesulitan luar biasa bagi manusia," akibat adanya kerusakan yang signifikan (Oliver, 1980). Bencana adalah "penghubung" antara peristiwa fisik ekstrem dan populasi manusia yang rentan (Susman \& O'keefe, 1983). Definisi seperti ini banyak diutarakan oleh ahli geografi tradisional.

Akademisi lainnya mendefinisikan bencana bukan sekedar sebagai peristiwa alam, namun sebagai peristiwa sosial. Sjoeberg mengkarakteristikkan bencana sebagai "gangguan yang parah, relatif tiba-tiba, dan sering tak terduga" dari sistem sosial yang dihasilkan dari beberapa peristiwa yang tidak dapat dikendalikan masyarakat (Sjoberg, 1962). Cisin \& Clark mengatakan bencana adalah peristiwa apa pun yang "secara serius mengganggu aktivitas normal." Dalam elaborasinya, para penulis ini menambahkan kualifikasi eksplisit (dari arti bencana), bahwa bencana dapat terjadi akibat ancaman yang tidak terwujud serta terjadi melebihi dampak yang sebenarnya (Cisin \& Clark, 1962).

Penjelasan yang lebih komprehensif dijelaskan oleh (Mcfarlane et al., 2006), yaitu: bencana adalah peristiwa yang berpotensi traumatis yang dialami individu, diawali dengan kondisi kritis, dan dibatasi waktu, dan bencana dapat disebabkan oleh peristiwa alam, teknologi, atau manusia. Palang Merah Internasional yang aktif bekerja memberi bantuan di lokasi bencana alam, mendefinisikan bencana berdasarkan dampak tingkat keparahan bukan pada dampak permulaan, bencana adalah peristiwa mengerikan yang tiba-tiba yang sangat mengganggu fungsi komunitas atau masyarakat dan menyebabkan kerugian material dan immaterial yang mungkin melebihi kemampuan manusia untuk mengatasinya dengan menggunakan sumber daya mereka sendiri (IFRC, 2020).

Bencana alam berdampak hampir di setiap sudut dunia. Bencana alam merenggut banyak nyawa dan merusak harta benda. Pusat Penelitian Epidemiologi Bencana (Center for Research on the Epidemiology of Disasters, 2018) mengidentifikasi 315 peristiwa bencana alam dengan 11.804 kematian pada tahun 2018. Jumlah bencana dan kausalitas yang lebih tinggi dilaporkan oleh Munich RE sebagaimana dikutip oleh (International Insurance Institute, 2020), di mana ada 820 peristiwa penyebab kerugian pada 2019 dan sekitar 9.000 orang di seluruh dunia kehilangan nyawanya karena bencana alam.

Indonesia berada di salah satu daerah paling rawan bencana alam di dunia dan berisiko tinggi akan berbagai bahaya, termasuk banjir, gempa bumi, tanah longsor, tsunami, gunung berapi, dan topan. Selama 30 tahun terakhir, rata-rata ada 289 bencana alam yang signifikan per tahun dan rata-rata kematian tahunan sekitar 8.000 akibat bencana alam (Global Facility for Disaster Reduction and Recovery, 2020). Terletak di Cincin Api Pasifik, setidaknya ada satu letusan gunung berapi yang signifikan dan satu gempa bumi besar di Indonesia setiap tahun dan tsunami besar dapat terjadi setiap lima tahun sekali (UNDP, 2020).

Ketika bencana terjadi, anak-anak adalah anggota masyarakat yang paling rentan (Balaban, 2006). Mereka berada pada risiko yang lebih tinggi mendapat tekanan dan trauma dibandingkan dengan orang dewasa (Ronan \& Johnston, 2005). Anak-anak rentan secara fisik, dan sering kebanyakan korban bencana adalah anak-anak. Mereka lebih rentan terhadap kematian, cedera, dan pelecehan. Mereka juga rentan secara psikologis dan jika dibiarkan dapat berkembang menjadi gangguan stres pasca-trauma (PTSD) atau gejala terkait lainnya (Peek, 2008), misalnya depresi, gangguan kecemasan, dan gangguan perilaku (Balaban, 2006).

Anak-anak rentan pada saat sebelum, selama dan setelah bencana. Bencana mengakibatkan gangguan berkelanjutan dalam kehidupan mereka, dari keluarga, sekolah, tempat tinggal, layanan kesehatan, pertemanan, dan bidang-bidang utama kehidupan lainnya; anak-anak menghadapi risiko perpisahan dari orangtua dan keluarga, kehilangan tempat tinggal dan harus pindah tempat tinggal, cedera, sakit, dan bahkan kematian (Fothergill, 2017). Bencana menyebabkan kesusahan bahkan kesusahan yang parah bagi 
anak-anak. Bencana memengaruhi kesehatan mental dan kesejahteraan anak selama bertahun-tahun sesudahnya (Bryant et al., 2018). Bencana memiliki dampak serius pada kesehatan mental dan fungsi sosial anak-anak (Norris et al., 2002). Dampak psikologis bencana bervariasi dan bisa terjadi pada rentang waktu yang panjang, kebanyakan orang pulih dengan cepat, sementara yang lain berkembang menjadi psikopatologi termasuk PTSD, depresi berat, gangguan kecemasan, dan bahkan penyalahgunaan zat terlarang (Shultz et al., 2017). Bencana alam berdampak pada kemampuan belajar jangka panjang anak-anak (Scott et al., 2014). Bencana dapat menurunkan prestasi belajar anak, memberi dampak perilaku anak dan terkadang membuat mereka menjadi agresif (Greenberg et al., 2002).

Meskipun anak-anak rentan dan sering digambarkan sebagai lemah, rapuh, pasif dan tidak mampu, mereka menunjukkan kemauan, keterampilan, dan kemampuan yang luar biasa menghadapi bencana yang terkadang tanpa disadari, dapat membantu diri mereka sendiri bahkan orang lain. Anak-anak bereaksi terhadap potensi bahaya (Masten \& Shaffer, 2006). Mereka bukan makhluk pasif, dan karena itu, perasaan dan pemikiran mereka mengenai bencana perlu dipahami. Mereka merespons rasa takut, bereaksi dan melawan ketakutan tersebut, dan juga mengembangkan mekanisme adaptif untuk bertahan hidup. Manusia, sejak usia dini, mengembangkan kemandirian mereka sendiri dalam beradaptasi dan menghadapi hal buruk yang menghadang (Dinkmeyer \& Dreikurs, 1979), sehingga penting untuk mempertimbangkan bahwa anak-anak mampu mengatasi kesulitan, menghadapi tantangan hidup (Osofsky \& Reuther, 2013).

Oleh karena itu sejak dini mereka harus dipersiapkan untuk menghadapi bencana. Anak-anak adalah manusia yang kreatif dan aktif dan mereka dapat terlibat dan berpotensi mendukung keluarga dalam kegiatan kesiapsiagaan dan pemulihan masyarakat. Anak-anak yang dapat bangkit kembali setelah kesulitan memiliki lebih banyak sumber daya dalam diri mereka, keluarga dan komunitas mereka (Osofsky \& Reuther, 2013). Kita harus meningkatkan akses mereka ke sumber daya, memberdayakan mereka untuk dapat, mendukung dan mendorong mereka untuk menjadi tangguh (resilient) dan mampu bangkit kembali setelah masa sulit.

Anak-anak perlu terekspos akan berbagai informasi mengenai bencana alam, tentu saja informasi tersebut muatan dan cara penyampaiannya perlu disesuaikan dengan usia anak. Salah satu alternatif yang mudah dan murah adalah mengenalkan konsep bencana alam lewat buku bacaan anak. Anak-anak terpapar pada media simbolis, seperti gambar cetak atau eletronik (Raynaudo \& Peralta, 2019). Buku, terutama buku bergambar adalah media pembelajaran yang paling banyak digunakan. Buku bergambar adalah sumber penting untuk memperoleh kosa kata bahasa baru, memahami konsep, dan media memberikan pelajaran untuk anak-anak. Salah satu manfaat buku bergambar sebagai sumber pendidikan adalah mereka dapat memberikan anak-anak akses ke konten yang tidak akan mereka alami dalam kehidupan sehari-hari mereka (Strouse et al., 2018).

Mengingat ancaman bencana alam yang bisa terjadi kapan saja dan dimana saja, anak perlu diberi pengetahuan dan latihan agar siap menghadapi bencana alam. Mereka perlu juga dipersiapkan untuk tahu bagaimana mereka bereaksi ketika bencana terjadi dan apa yang harus mereka lakukan pasca bencana. Dengan memperkenalkan tentang bencana, berbagai resiko dan cara meresponnya, maka anak menjadi lebih siap.

Penelitian ini difokuskan pada bagaimana tampilan dan isi pembelajaran mitigasi bencana alam gempa bumi pada buku bacaan bergambar anak. Bencana alam yang dikaji hanya tentang gempa bumi dan buku yang dianalisis hanya satu buku yaitu buku anak seri pengetahuan bencana alam "Aku Tahu Gempa Bumi." Buku ini merupakan salah satu seri dari enam buku seri bencana alam lainnya yang dikarang oleh Putri Febrianti. Keenam buku seri bencana alam adalah 1) Aku Tahu Gempa Bumi 2) Aku Tahu Gunung Meletus 3) Aku Tahu Tsunami 4) Yuk Cegah Longsor! 5) Yuk Cegah Banjir! 6)Yuk Cegah Kebakaran. Pembuatan buku ini dibantu oleh editor Renika Veronika dan Nurlailah. Sedangkan yang 
membantu membuat ilustrasi gambar pada buku adalah Regi Wardiansyah. Cetakan pertama dilakukan pada bulan November tahun 2015. Buku setebal 30 halaman ini, diterbitkan oleh PT. Srikandi Empat Widya Utama (SEWU) yang berasal dari Kota Bandung. Buku ini dipilih menjadi kajian penelitian mempertimbangkan beberapa alasan: pertama, buku ini berada pada peringkat pertama pada Google search engine, ketika menggunakan kata kunci "buku bacaan anak bencana alam," dan "buku anak gempa bumi." Kedua, buku ini mudah didapatkan dari berbagai situs marketplace seperti shopee, Bukalapak dan Tokopedia. Ketiga, harga buku yang sangat terjangkau yaitu hanya dua belas ribu rupiah. Keempat, buku ini dimiliki oleh PAUD tempat mengajar narasumber guru yang diwawancara.

Buku bacaan harus menarik perhatian anak dan membuat mereka mau belajar. Buku bacaan tentang mitigasi bencana gempa bumi dapat menjadi buku pengayaan untuk tambahan pengetahuan anak. Pusat Kurikulum dan Perbukuan menjelaskan secara rinci panduan pemilihan buku nonteks pelajaran, buku pengayaan bagi pendidikan anak usia dini sebagai berikut: Pertama, isi buku sesuai dengan jenjang dan karakteristik pendidikan anak usia dini. Kedua, peserta didik ditumbuhkan minat baca mereka melalui simbol makna seperti angka, huruf, gambar dan bentuk simbolik lainnya. Ketiga, buku memiliki ilustrasi yang menarik, beragam jenis, dengan teks yang mudah dipahami jalan ceritanya (Pusat Kurikulum dan Perbukuan, 2018).

Mengacu pada ketentuan diatas, peneliti mendalami bagaimana tampilan dan isi buku berdasarkan perspektif peneliti, serta pandangan orang tua dan guru mengenai tampilan dan isi buku tersebut dalam mempersiapkan anak menghadapi bencana alam gempa bumi. Diharapkan dengan penelitian ini kita dapat memahami bagaimana kita bisa memiliih buku mitigasi bencana alam bagi anak usia dini yang berkualitas dan kemudian dapat memberi masukan untuk penulisan buku selanjutnya agar bisa lebih efektif memberi pengetahuan dan keterampilan anak menghadapi bencana alam.

\section{METODOLOGI}

Penelitian ini menggunakan metode deskriptif kualitatif yang menggabungkan teknik analisis buku dengan wawancara mendalam. Peneliti menerapkan studi kualitatif untuk menyelidiki dan memahami masalah secara mendalam dan komprehensif (Creswell, 2007). Metode deskriptif kualitatif dianggap tepat diterapkan karena sifat penelitian ini yang memang ingin mengeksplorasi secara mendalam bagaimana pembelajaran kesiapsiagaan bencana alam gempa bumi pada buku bacaan bergambar. Penelitian ini tidak bertujuan untuk membuktikan teori, namun diharapkan dapat menghasilkan asersi mengenai buku yang bisa secara efektif memberi pengetahuan dan keterampilan anak dalam menghadapi bencana alam, khususnya bencana alam gempa bumi.

Sumber data penelitian adalah hasil analisis buku yang dilakukan oleh peneliti dan naskah transkrip hasil wawancara. Buku yang dikaji hanya satu buku. Peneliti melakukan analisis dengan menggunakan tabel analisis yang dirumuskan oleh peneliti dengan mengacu pada pedoman buku non-teks pelajaran dari Pusat Kurikulum dan Perbukuan. Peneliti mengkaji tampilan, isi dan pesan dari buku anak seri pengetahuan bencana alam "Aku Tahu Gempa Bumi" dari halaman sampul hingga halaman terakhir.

Wawancara dilakukan dengan tiga orang tua dan tiga orang guru PAUD. Wawancara semi terstruktur digunakan untuk menyelami bagaimana pandangan narasumber mengenai tampilan, isi dan pesan dari buku anak seri pengetahuan bencana alam "Aku Tahu Gempa Bumi." Pemilihan sampel adalah dengan teknik purposive sampling, narasumber harus memenuhi syarat, yaitu: adalah orang tua yang memiliki anak usia dini atau guru yang mengajar pada jenjang pendidikan anak usia dini. 


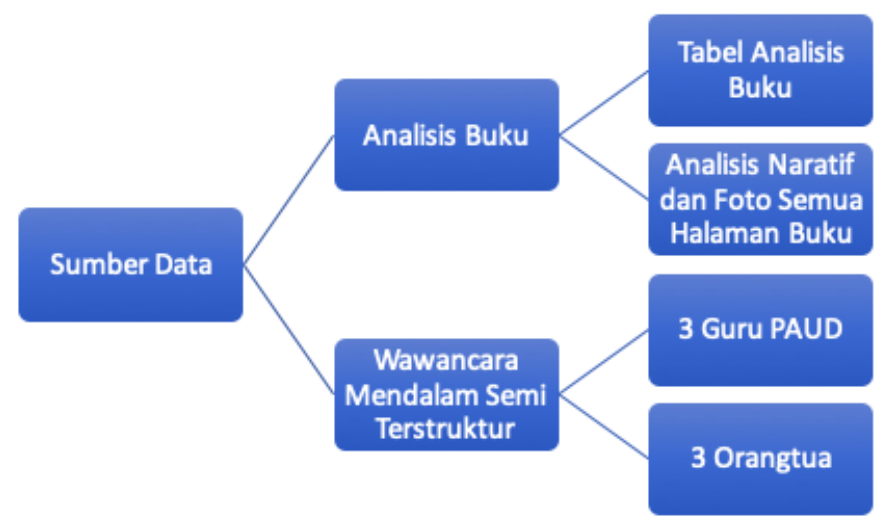

\section{Gambar 1. Sumber Data Penelitian}

Teknik pengolahan data penelitian adalah: pertama peneliti menyelesaikan analisis buku secara umum dan analisis detail atas setiap lembar halaman buku. Kemudian peneliti menyalin hasil analisis buku pada tabel catatan hasil analisis buku yang berisi narasi deskriptif dari analisis tampilan, isi dan pesan buku dengan dilengkapi oleh poto setiap halamannya. Dalam waktu bersamaan peneliti mewawancara narasumber. Setelah dilakukan wawancara maka peneliti mentranskrip setiap rekaman wawancara. Data analisis dan transkrip dirapihkan dalam folder-folder sesuai kategori, hal ini bertujuan untuk memudahkan peneliti dalam analisis hasil.

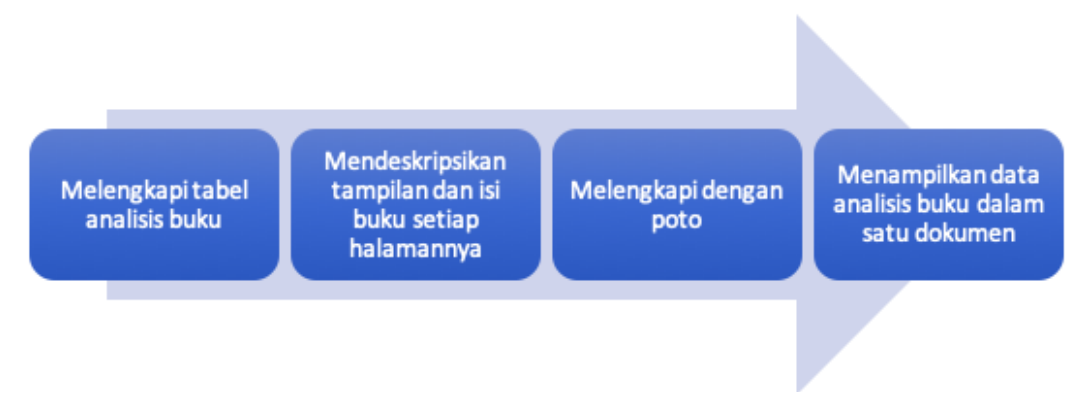

Gambar 2. Langkah pengolahan Data Hasil Analisis Buku

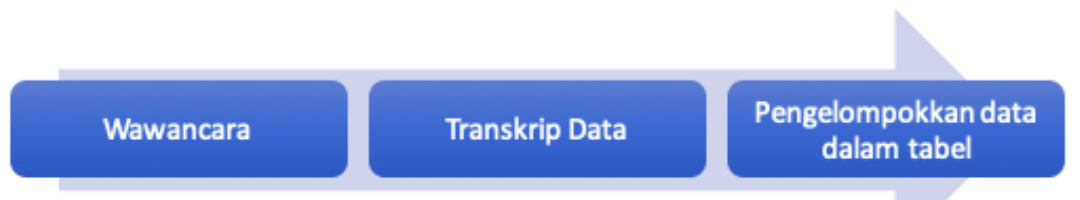

\section{Gambar 3. Langkah Pengolahan Data Hasil Wawancara}

Tahapan pertama yang dilakukan oleh peneliti dalam menganalisis data adalah dengan melakukan reduksi data, pemilihan, pemfokusan, penyederhanaan dan pentransformasian data dalam catatan-catatan tertulis. Kemudian peneliti melakukan display data, data yang sudah di reduksi kemudian ditampilkan dalam bentuk tabel. Selanjutnya, peneliti melakukan kodifikasi, memilah dan memilih tema yang muncul dari data yang ada. Baru setelah itu peneliti membuat gambaran kesimpulan dari data yang telah dianalisis 


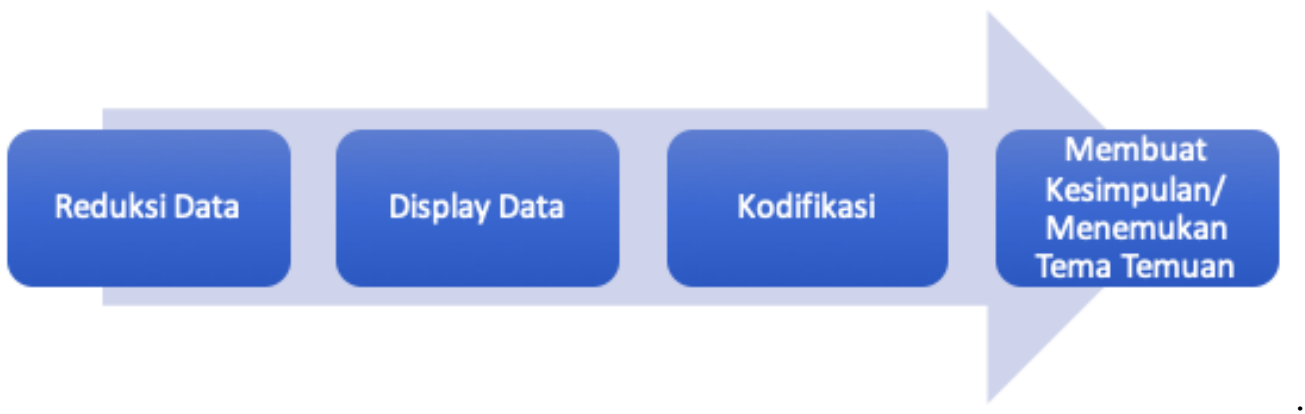

Gambar 4. Langkah Analisis Data

Peneliti mengelola dengan baik data hasil wawancara dan melakukan triangulasi sumber data untuk menjaga keabsahan dan validitas penelitian. Selain itu pemeriksaan anggota atau member check dilakukan oleh peneliti untuk memastikan bahwa peneliti memahami dan menuliskan dengan benar apa yang dikatakan oleh narasumber. Peneliti juga mendiskusikan hasil analisis buku yang dilakukannya dengan narasumber untuk mengecek cara berpikir analasisisnya tepat dan melihat bahwa analisis buku telah dilakukan dengan baik dan konsisten mengikuti panduan penelitian.

\section{HASIL DAN PEMBAHASAN}

Bagaimana tampilan dan penyampaian pembelajaran mitigasi bencana alam gempa bumi dalam buku bacaan bergambar anak? Buku bacaan bergambar yang dimaksud adalah buku pengetahuan bencana alam "Aku Tahu Gempa Bumi"? Dari data yang terkumpul, peneliti menyimpulkan bahwa: 1) buku tersebut memiliki gambar yang informatif dan menarik; (2) bahasa pada buku singkat, jelas dan mudah dipahami oleh anak; dan (3) buku memberi pengetahuan dan memotivasi anak untuk siaga bencana.

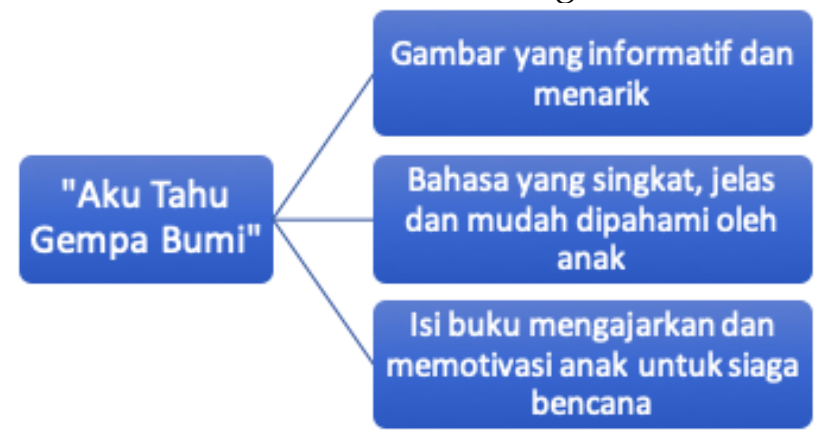

Gambar 5. Hasil Analisis Penelitian

\section{Gambar yang Informatif dan Menarik}

Pedoman Buku Nonteks Pelajaran dari standar Pusat Kurikulum dan Perbukuan (Pusat Kurikulum dan Perbukuan, 2018) menyebutkan bahwa kriteria sampul buku harus memiliki ilustrasi sampul yang menggambarkan isi buku, dan buku seharusnya menggunakan gambar yang mencirikan isi buku. Buku yang informatif dan menarik, bukan hanya menampilkan ilustrasi yang bagus, namun juga memiliki warna yang menarik dan memberikan gambar yang informatif.

Hsiao dan Chang yang mendeskripsikan 5 aspek gaya buku bergambar yang dapat menarik pembaca anak-anak: tata letak halaman, font, warna, kertas, dan penjilidan (Hsiao \& Chang, 2015). Tata letak halaman mencakup sampul, lembar akhir, dan halaman judul. Sampul adalah aspek penting karena memberi kontribusi pada kesan pertama pengamat.

Peneliti menyimpulkan bahwa buku "Aku Tahu Gempa Bumi" memiliki gambar yang informatif dan menarik. Tampilan pada sampul buku mencirikan gambaran pasca terjadinya gempa bumi, cuaca yang sedikit gelap mengisyaratkan bahwa telah terjadinya bencana 
alam. Buku juga menampilkan gambar gedung-gedung yang roboh tidak beraturan, pohonpohon yang tumbang, dan kendaraan rusak tertimpa puing-puing bangunan.

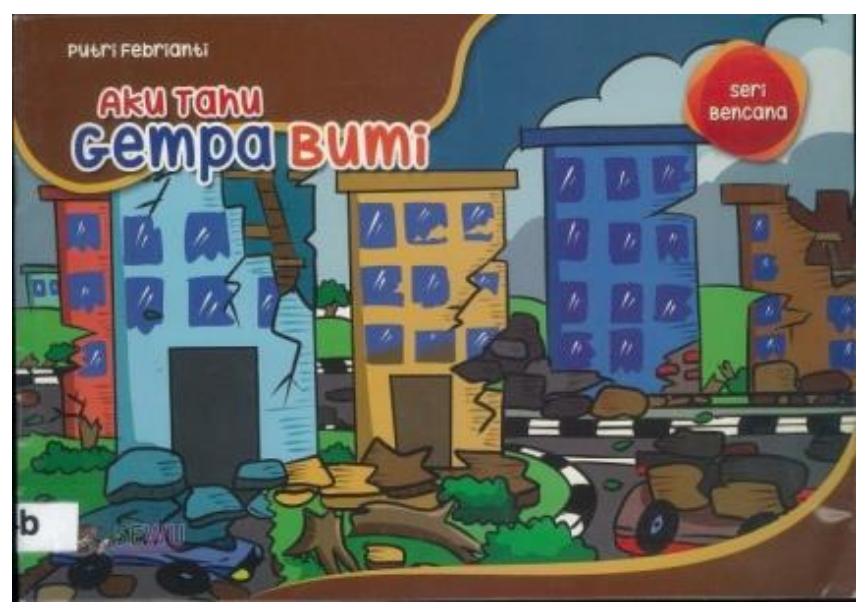

Gambar 6. Sampul Buku “Aku Tahu Gempa Bumi” (Putri Febriyanti, 2015)

Warna yang digunakan pada sampul buku "Aku Tahu Gempa Bumi" cukup menarik, warna yang digunakan cukup banyak dan didominasi dengan aneka warna yang cerah. Sampul buku juga sudah menjelaskan apa yang akan dibahas dalam buku, yaitu tentang bencana alam gempa bumi. Gambar buku menampilkan suasana pasca terjadinya gempa bumi. Penggunaan buku bergambar pada pembelajaran anak usia dini adalah penting. Malah sebaiknya buku berupa Big Book berukuran besar dengan gambar yang menarik dan tulisan yang besar-besar (Putri Febriyanti, 2015)

Narasumber $\mathrm{S}$ dan L sependapat dengan analisis peneliti, mereka berkomentar bahwa:

"Secara umum bukunya banyak warna, menarik untuk anak usia dini. Gambar yang digunakan memberikan contoh kepada anak-anak untuk mengenal gempa bumi, memperlihatkan gunung yang meletus akibat gempa, dan bangunan-bangunan runtuh yang merupakan dampak dari gempa bumi." [S/2019]

"Untuk anak TK dilihat dari warna sudah menarik, sampulnya menarik karena warnawarni, gambarnya cukup menampilkan apa yang ingin disampaikan, menggambarkan tentang bencana gempa bumi." [L/2019]

Pada halaman isi, buku juga dipenuhi oleh gambar yang menarik. Narasumber Z dan D Buku menilai bahwa buku ini memiliki gambar indah, sesuai dengan perkembangan anak usia dini dan informatif. Berikut adalah cuplikan pernyataan mereka mengenai hal ini:

"Secara umum tampilan buku ini adalah tampak seperti buku-buku seri cerita pada umumnya untuk anak-anak ini terlihat dari gambarnya yang menarik" [Z/2019]

"Tampilan bukunya bagus, seperti pada umumnya buku cerita pada anak banyak warna dan gambarnya menarik. Bagus gambarnya cukup besar jadi anak-anak bisa melihat dengan jelas." [D/2019]

Gambar pada buku mendeskripsikan konsep ide, tindakan dan peristiwa yang terkait dengan isi cerita. Ilustrasi gambar yang ditampilkan sesuai dengan alur cerita. Sebagai contoh, pada buku ini digambarkan secara rinci bagaimana peristiwa terjadinya gempa: adanya titik gempa, pusat gempa, patahan atau retakan dan gelombang seismic atau gelombang yang merambat melalui bumi. Gambar yang ditampilkan berbentuk sederhana, yaitu tanah luas tempat terjadi gempa dengan keterangan-keterangan peristiwa alam terkait. Titik gempa diberi tanda titik, gelombang seismic terlihat mengitari titik gempa tersebut, dan 
adanya patahan di area sekitar titik gempa. Gambar yang sederhana ini bisa menjelaskan konsep yang rumit. Gambar yang ditampilkan memudahkan anak paham istilah-istilah terkait gempa.

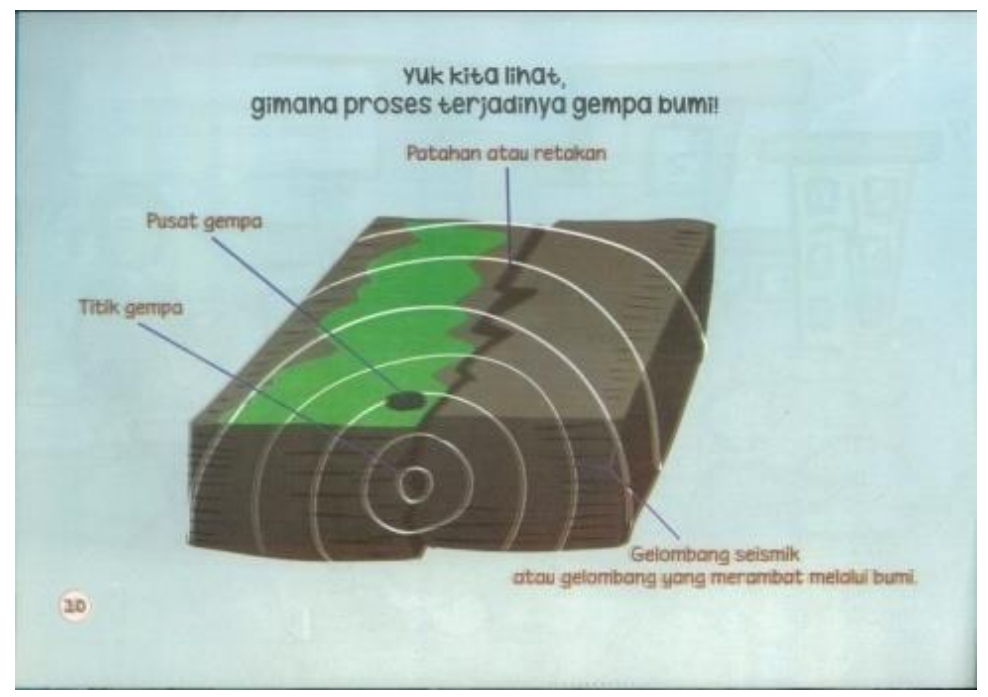

Gambar 7. Peristiwa Terjadinya Gempa (Putri Febriyanti, 2015, hal. 10)

Ketika anak tertarik dengan gambar, maka ia menjadi ingin tahu lebih banyak isi buku tersebut. Fitur tertentu dari buku bergambar, seperti konten spesifik yang ditampilkan oleh penulis, atau cara konten disajikan, dapat memengaruhi kecenderungan anak-anak untuk mempelajari dan mentransfer konten pendidikan ke situasi dunia nyata (Strouse et al., 2018) dan (Simcock \& DeLoache, 2006). Gambar yang informatif pada buku dan bagaimana pesan penulis dikemas, bisa menginspirasi anak-anak untuk meniru tindakan tersebut. Anak sejak sangat kecil sudah mulai berpikir secara simbolis. Mereka memahami bahwa gambar mewakili objek nyata. Gambaran gempa bumi pada buku "Aku Tahu Gempa Bumi” adalah gambar ilustrasi bukan poto realisme, anak paham bahwa gambar tersebut mewakili obyek nyata. Anak menghubungkan pemahaman yang didapat dari buku dengan kejadian dunia nyata. Diharapkan jika mereka tahu tanda-tanda gempa dari buku, ketika gempa sesungguhnya terjadi, mereka dapat menggunakan informasi dari teks ke tindakan nyata, sehingga mereka mereka secara otomatis berupaya menyelamatkan diri sebagaiman paparan lanjutan dari buku tersebut yang menjelaskan langkah-langkah penyelamatan diri.

\section{Bahasa yang singkat, jelas, dan mudah dipahami oleh anak}

Buku ini memberikan edukasi bencana alam yang singkat, jelas dan mudah dipahami oleh anak. Informasi pengetahuan bencana alam gempa bumi pada buku menggunakan kalimat yang cukup sederhana, pengemasan kalimat cukup mudah untuk diterima oleh anak. Pada halaman tiga, seorang anak perempuan memakai baju oranye dan membawa tas ransel pink, berada di depan rumahnya. Anak itu berkata: "kata ayahku, gempa bumi adalah salah satu bencana alam. Gempa bumi terjadi karena pegereseran lempeng atau lapisan bumi." Walau kalimat ini tidak sepenuhnya mudah dipahami anak, namun kadang kala kita perlu menantang anak untuk belajar kosa kata baru. Guru atau orangtua ketika membacakan cerita ini bisa menjelaskan beberapa kosa kata sulit dari kalimat ini, misal: pergeseran lempeng dan lapisan bumi. Pemaparan konsep gempa dilakukan dengan bahasa santai dan seperti sering terjadi anak sering sekali belajar konsep rumit dari orangtuanya dan kemudian membaginya dengan kawan-kawannya. Pada cerita, anak itu dengan bangganya membagi pengetahuan yang ia dapat dari ayahnya. 


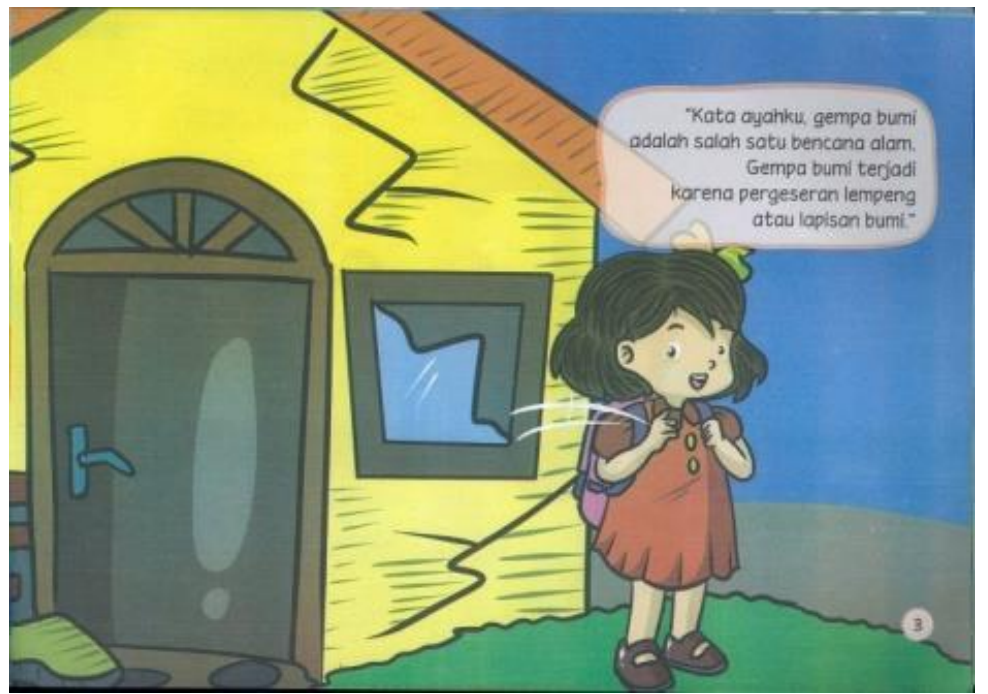

Gambar 8. Pengertian Gempa (Putri Febriyanti, 2015, hal. 3)

Pedoman Buku Nonteks Pelajaran (Pusat Kurikulum dan Perbukuan, 2018), menyebutkan bahwa kriteria buku harus menggunakan ilustrasi yang detail, yang dapat digunakan oleh orangtua atau guru dalam mendiskusikan isi cerita. Gambar yang digunakan dalam buku juga harus sesuai dengan alur cerita. Ini bertujuan agar anak mudah paham melalui gambar untuk menangkap penjelasan apa yang akan disampaikan oleh buku.

Buku "Aku tahu gempa Bumi" menyajikan banyak informasi penting dalam bentuk gambar dengan kalimat-kalimat sederhana dan pendek. Halaman buku tidak dipenuhi dengan teks yang banyak. Jalinan cerita menarik dan dekat dengan kehidupan sehari-hari anak. L dan $S$ berpendapat pengemasan pengetahuan gempa bumi penggambaran seorang anak perempuan yang menjelaskan sedikit arti dari gempa, dari informasi yang didapat dari ayahnya, sangat menarik dan terkesan natural. Gambar yang digunakan mendukung, jika anak tidak paham teks, mereka kemungkinan bisa lebih cepat paham dari gambar yang ada.

\section{"Penyampaiannya cukup baik, pengetahuan yang dijelaskan dapat tersampaikan." [L/2019] \\ "Penyampaian tentang gempa bumi nya baik karena menggunakan gambar-gambar yang mendukung untuk menjelaskan pengetahuan yang ingin dismapaikan." [S/2019]}

Narasumber Z dan D berpendapat bahwa buku "Aku Tahu Gempa Bumi" menggunakan alur cerita dan genre yang mudah dipahami sehingga anak tidak bingung memahami isi ceritanya. Buku ini memberikan pengetahuan agar anak tidak panik pada saat bencana gempa bumi tiba-tiba terjadi. Selain itu, buku ini juga mempersiapkan mental anak pasca bencana, agar mereka tidak trauma yang berlebihan karena mereka sudah mengetahui tentang bencana alam gempa bumi yang adalah bagian dari fenomena kehidupan. Beirkut adalah kutipan wawancara dengan $\mathrm{Z}$ dan $\mathrm{D}$ yang menjeaskan hal tersebut:

"Isi buku secara umum menggambarkan tentang pengalaman gempa bumi pada anak usia dini dan cukup baik, dengan disertai pengenalan gempa bumi. Jadi secara umum buku ini sangat baik. Sepert yang saya sampaikan tadi ada alur ceritanya tidak rumit, alur cerita simpel berisi dan mengena dan jadi cocok untuk anak usia dini." [Z/2019]

"Genre yang disuguhkan oleh buku bagus jadi memiliki pesan untuk anak usia dini harus lebih cepat mengenal bencana alam yang terjadi sejak dini, termasuk nasihat juga kan untuk anak dan bagus untuk pengetahuan anak." [D/2019] 
Contoh lainnya bagaimana buku ini secara natural mengenalkan berbagai informasi terkait gempa bumi adalah pada halaman tigabelas dijalin cerita bagaimana anak-anak bisa merasakan goncangan gempa dengan masuk ke dalam ruang simulasi gempa yang di museum sains. Digambarkan dalam cerita buku, guru mengajak anak-anak muridnya untuk berkunjung ke museum sains, di museum tersebut terdapat tempat simulasi bencana alam gempa bumi yang dapat digunakan oleh anak-anak. Ada lima orang anak yang masuk ke ruang simulasi bencana, anak-anak duduk bersama dilantai ruangan itu. Seorang petugas museum perempuan terlihat memencet sebuah tombol berwarna merah, yang merupakan tombol untuk memulai simulasi. Terlihat dua orang anak tersenyum merasakan sensasi goncangan gempa, seorang anak yang duduk di depan terlihat kebingungan, sedang dua orang anak dibelakang berpegangan tangan dengan ekspresi ketakutan. Kelima anak ini digambarkan merasakan sensasi bencana alam gempa bumi yang dibuat semirip mungkin dengan kejadian aslinya pada ruang simulasi gempa. Sangat menarik sekali bagaimana penulis membawa pembaca pada pengalaman berkunjung ke museum. Ini memudahkan anak untuk memahaminya karena mereka kebanyakan sudah pernah berkunjung ke museum dan mungkin sudah ada yang pernah mencoba simulasi gempa yang diceritakan pada buku. Guru yang diwawancara mengatakan dia mensimulasikan kejadian gempa di kelas dengan cara mengajak anak-anak untuk menggerakkan badan ke kiri dan ke kanan, dan menghentak-hentakkan kaki ke lantai dengan kuat.

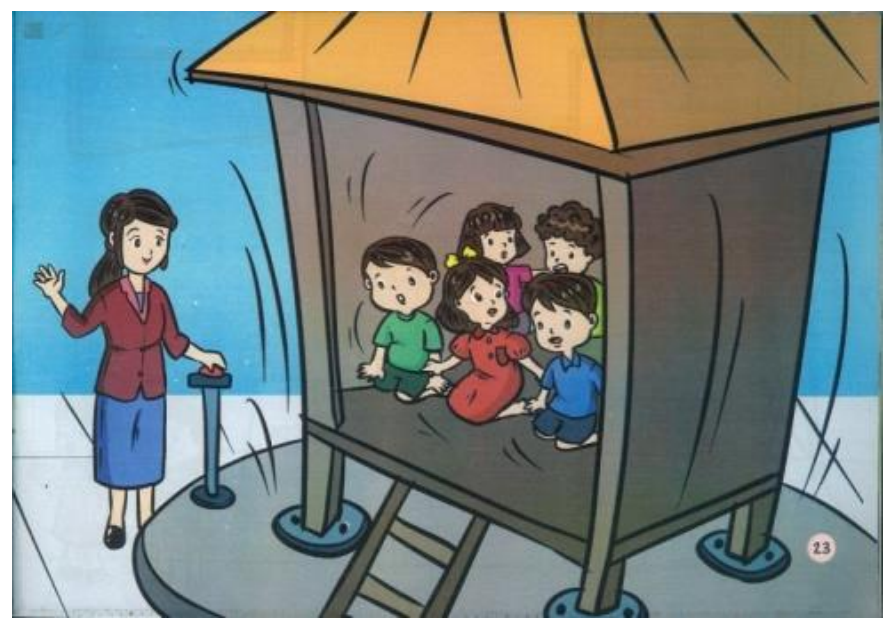

Gambar 10. Ruang Simulasi Gempa (Putri Febriyanti, 2015, hal. 23)

Isi buku bergambar harus ringkas, mudah dipahami, dilengkapi plot yang masuk akal, dan mengandung nilai-nilai positif (Hsiao \& Chang, 2015). Yang paling penting, buku bergambar harus menarik bagi anak-anak dan beresonansi dengan kehidupan mereka, sehingga memicu minat mereka dan membimbing mereka untuk memahami makna cerita dan mendapatkan inspirasi. Daripada sekedar menjelaskan apa itu gempa bumi, penulis buku "Aku Tahu Gempa Bumi" mengemas ceritanya dengan kisah anak kecil yang tahu apa arti gempa bumi dari ayahnya. Tidak hanya menjelaskan apa itu goncangan gempa, penulis menceritakan pengalaman anak-anak mengunjungi museum sains dan masuk ke ruang simulasi gempa. Jalinan cerita yang natural dan dekat dengan anak-anak diharapkan dapat memudahkan anak memahami konsep-konsep terkait bencana yang kebanyakan kompleks dan merupakan rangkaian kosa kata baru bagi anak.

\section{Buku Memberi Pengetahuan dan Memotivasi Anak untuk Siaga Bencana}

Buku ini memberikan pengetahuan tentang bencana alam gempa bumi dan memberikan motivasi pada anak agar siaga menghadapi bencana alam. Pada satu halaman terdapat pesan informatif berupa hal-hal yang harus dilakukan ketika gempa bumi terjadi. 
Ada tulisan besar di halaman tersebut "Yuk, selamatkan diri saat terjadi gempa bumi." Terdapat gambar tokoh utama, anak perempuan, berada ditengah halaman dengan tangan menunjuk ke atas ke arah kalimat tersebut. Kalimat yang diawali dengan kata "yuk" menunjukkan ajakkan. Terdapat empat ajakan yang dijelaskan dengan gambar yang sangat deskriptif. Gambar pertama, seorang anak perempuan duduk merangkak dibawah meja, diatas meja barang-barang berjatuhan, anak itu menyelamatkan diri dengan berlindung di bawah meja. Gambar kedua, dua anak laki-laki bercelana panjang, terlihat lari keluar dari gedung bertingkat, nampak terlihat retakkan tanah disekitaranya, wajah kedua anak itu menunjukkan ekspresi ketakukan dan waspada, tangannya mengepal menggambarkan mereka lari sekencang-kencangnya. Gambar ketiga, seorang remaja berlari keluar dari kendaraan, dia menengok ke sebelah kanan seperti mencari kearah mana dia harus berlari. Dia berada di jalan raya, ada dua mobil dibelakangnya, terlihat jalanan retak. Gambar terakhir, ada 4 orang berlarian dengan jarak yang tidak berdekatan, seorang bapak yang berlari diikuti dengan anak lelaki, dan ada lagi lelaki dewasa berpakaian rapih diikuti dengan anak perempuan kecil yang berlari tak jauh darinya. Mereka semua berlari menuju halaman luas. Mereka berasal dari gedung tinggi.

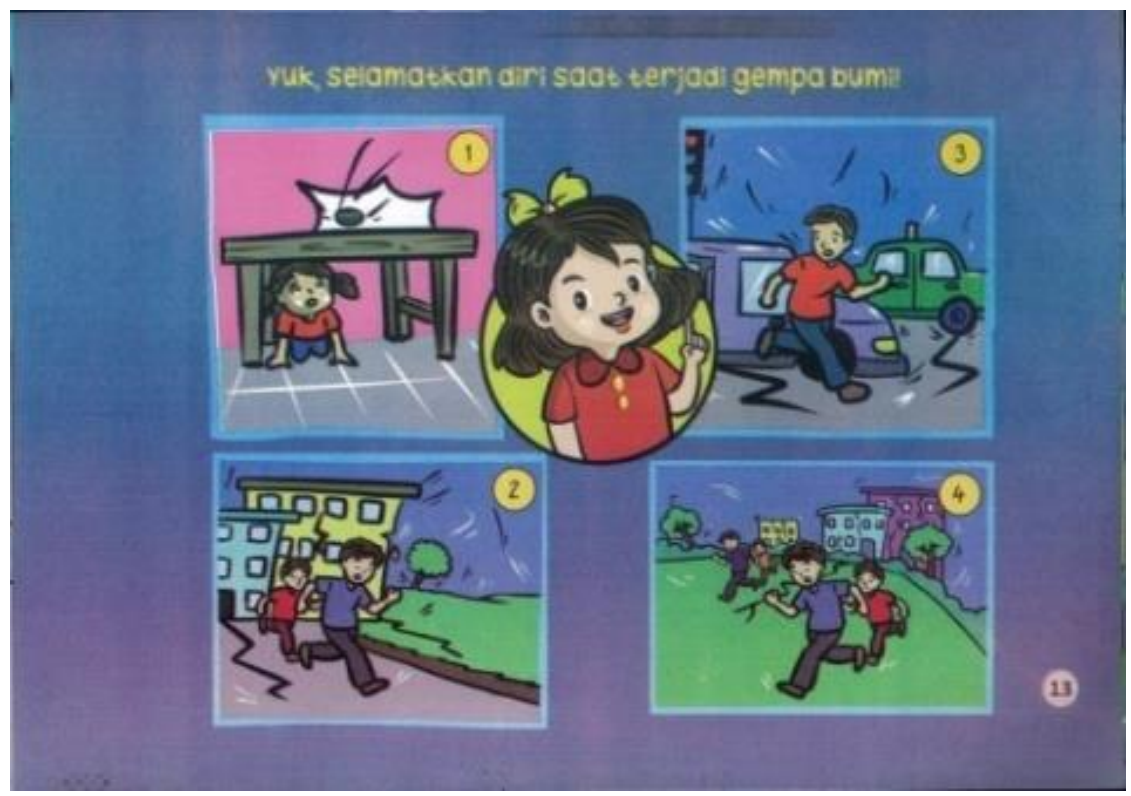

Gambar 11. Penyelamatan Diri Ketika Gempa (Putri Febriyanti, 2015, hal. 13)

Gambar tersebut menjelaskan secara terperinci apa yang harus dilakukan anak-anak ketika gempa bumi terjadi. Tidak perlu menggunakan kalimat yang panjang dan bahasa ilmiah yang sulit dimengerti. Anak usia dini, banyak yang belum lancar membaca, namun mereka dapat memahami pesan buku dengan sekedar melihat gambarnya. Gambar ini memberi pengetahuan apa yang harus dilakukan jika terjadi gempa dan memberikan motivasi agar anak siap siaga, tahu ketika terjadi bencana, mereka harus bertindak cepat menyelamatkan diri mereka.

Narasumber U menggaris bawahi hasil analisis buku oleh peneliti, dia sependapat bahwa buku ini memberi pemahaman dengan cara sederhana kepada anak-anak agar mereka waspada bencana dan tahu apa yang harus dilakukan ketika bencana, seperti gempa bumi, terjadi.

"Dalam buku mengajarkan kepada anak-anak bahwa harus berhati-hati apabila terjadi gempa, apa yang harus dilakukan pada saat terjadi gempa, dan membantu sesama apabila terjadi kesulitan." [U/2019] 
Buku bergambar sudah banyak digunakan untuk mengenalkan berbagai konsep, yang kadang rumit atau kompleks, kepada anak usia dini. Buku bergambar memberikan informasi terkait konsep tersebut dan memotivasi anak untuk meniru tindakan positif yang diceritakan pada buku. Cerita dan dongeng menginspirasi dan memotivasi anak untuk berperilaku prososial (Mustika Sari et al., 2018). Hsiao dan Shih meneliti bagaimana pemahaman konsep lingkungan anak-anak dapat meningkat pesat mengikuti kegiatan membaca buku bergambar yang menceritakan berbagai cara pelestarian alam dan proses daur ulang. Mereka menyimpulkan bahwa buku cerita bergambar anak membuat anak-anak menjadi paham cara mengurangi sampah, dan bagaimana menggunakan lebih sedikit air, listrik, dan kertas, ditambah perilaku ramah lingkungan lainnya (Hsiao \& Shih, 2016). Hal ini menginspirasi anak-anak untuk menghemat sumber daya melalui tindakan mereka sendiri; misalnya, anak-anak menggunakan lebih sedikit air ketika mencuci tangan dan menyikat gigi dan membawa saputangan mereka sendiri ke sekolah. Selain itu, anak-anak juga menggunakan lebih sedikit kertas gambar dan mematikan lampu dan televisi tanpa diingatkan untuk menghemat listrik.

Crawford \& Shores mengatakan bahwa para pendidik guru dapat mempertimbangkan untuk menggunakan buku gambar berkualitas tinggi sebagai mitra untuk membantu anak usia dini memahami dan menavigasi realitas dunia yang menyakitkan saat ini, seperti tentang peperangan, pengungsi, kemiskinan, tuna wisma, dan kelaparan (Crawford et al., 2019). Dari sudut pandang kritis, buku bacaan bergambar juga memiliki potensi untuk mencerminkan dan membentuk empati dan tindakan sehubungan dengan situasi sulit ini.

Buku cerita bergambar juga diyakini dapat membantu anak di masa mereka mengalami krisi kehidupan. Ketika sebuah krisis mengguncang kehidupan seorang anak, seringkali tergantung pada para guru untuk mengenali dan mengidentifikasi tanda-tanda bahwa anak tersebut menderita stres yang berkelanjutan, dan untuk membantu orang tua membuat keputusan yang tepat mengenai langkah-langkah selanjutnya (Grace \& Shores, 2010). Meskipun sebagian besar guru tidak dapat memberikan terapi kepada anak-anak di bawah tekanan traumatis, mereka sudah memiliki alat yang mereka butuhkan untuk membantu anak-anak mengatasi: buku cerita.

San Agustin dkk meneliti tentang efek jangka panjang dari intervensi Reach Out and Read (ROR) yang dimodifikasi setelah topan di Filipina. Dua bulan setelah Topan Haiyan, dokter melatih orang tua dan anak-anak membaca dengan keras dan membagikan buku bergambar. Tiga belas bulan kemudian, peserta menggambarkan reaksi mereka terhadap topan dan intervensi kesehatan jiwa (ROR) yang telah dilakukan selama ini. Subjek penelitian adalah 113 orang tua kelas pekerja dan anak-anak mereka, usia 6 bulan hingga 11 tahun (San Agustin et al., 2019). Data menunjukkan bahwa buku-buku itu telah menjadi pendukung pendidikan dan membantu anak-anak untuk merasa bahagia lagi. Kesimpulan penelitian adalah lebih dari setahun setelah bencana alam, para penyintas (survivors) merasa tertolong dengan intervensi sederhana yang menyediakan buku bergambar dan panduan tentang membaca dengan keras; banyak yang terus menggunakan buku-buku itu. Intervensi berbasis buku dapat membantu mengurangi dampak bencana alam.

Guru dapat menggunakan literatur anak-anak untuk membantu anak-anak membangun ketahanan (resiliency) ketika mereka menghadapi masa-masa sulit: "Saat guru mendukung siswa untuk membaca dan merenungkan karakter yang menghadapi perselisihan dan kesulitan namun menemukan cara-cara positif untuk melewati situasi sulit, mereka membantu mempersiapkan mereka untuk kehidupan" (Lacina et al., 2016). Anak belajar menjadi kuat dari pengalaman tokoh pada cerita. Mereka menjadi terinspirasi menjadi "bisa." Diharapkan buku seperti "Aku Tahu Gempa Bumi" juga bisa sukses memotivasi anak menjadi tangguh menghadapi berbagai krisis kehidupan. Pernyataan ini belum menjadi kesimpulan penelitian ini, karena memang peneliti tidak sampai meneliti 
dampak buku tersebut pada pengetahuan dan kesiapsiagaan anak-anak. Namun harapan ini sangat mungkin terwujud jika kita bisa menghasilkan buku pengetahuan bencana alam yang berkualitas.

\section{SIMPULAN}

Sudah semestinya kita mempersiapkan anak menghadapi bencana alam sejak usia dini. Intensitas dan dampak bencana alam di Indonesia bisa diminimalisir dengan ilmu pengetahuan dan juga dengan mempersiapkan setiap warga negara, dari yang muda hingga tua tentang bencana alam. Buku adalah salah satu media efektif untuk diseminasi pengetahuan dan keterampilan yang dapat mempersiapkan anak usia dini menghadapi bencana alam. Penelitian ini menyimpulkan bahwa buku ini memiliki gambar yang informatif dan menarik; bahasa yang digunakan singkat, jelas dan mudah dipahami; dan buku ini memberi pengetahuan dan memotivasi anak untuk siap siaga bencana. Penelitian ini dilakukan mengikuti kaidah ilmiah yang terencana, namun masih terdapat beberapa keterbatasan, misalnya penelitian ini hanya menganalisis satu buku saja dan mengenai satu jenis bencana yaitu gempa bumi. Akan menarik sekali untuk membandingkan beberapa buku dan juga menganalisis upaya menyiapkan anak menghadapi beragam bencana alam. Penelitian ini juga akan memiliki dampak lebih besar jika kajiannya tidak hanya menggunakan metode kualitatif, peneliti selanjutnya bisa memulainya dengan menampilkan data statistik jumlah buku bencana alam bagi anak dan kemudian melakukan kajian komparatif atas kualitas beberapa buku-buku tersebut. Penelitian juga dapat dilengkapi dengan kajian tentang tingkat pemahaman siswa atau tingkat kesiapsiapan siswa menghadapi bencana gempa bumi setelah belajar dari buku "Aku Tahu Gempa Bumi."

\section{UCAPAN TERIMAKASIH}

Terimakasih kami ucapkan kepada semua pihak yang berperan dalam proses penelitian ini, terutama kepada segenap pimpinan dan civitas akademika program studi Pendidikan Islam Anak Usia Dini, Fakultas Ilmu Tarbiyah dan Keguruan, UIN Syarif Hidayatullah Jakarta.

\section{DAFTAR PUSTAKA}

Anggraeni, D., Hartati, S., \& Nurani, Y. (2019). Implementasi Metode Bercerita dan Harga Diri dalam Meningkatkan Kemampuan Berbicara Anak Usia Dini. Jurnal Obsesi : Jurnal Pendidikan Anak Usia Dini, 3(2), 404. https:/ / doi.org/10.31004/obsesi.v3i2.224

Balaban, V. (2006). Psychological Assessment of Children in Disasters and Emergencies. Disasters, 30(2), 178-198. https:/ / doi.org/10.1111/j.0361-3666.2006.00314.x

Bryant, R. A., Gibbs, L., Gallagher, H. C., Pattison, P., Lusher, D., MacDougall, C., Harms, L., Block, K., Sinnott, V., Ireton, G., Richardson, J., \& Forbes, D. (2018). Longitudinal study of changing psychological outcomes following the Victorian Black Saturday bushfires. Australian $\mathcal{E}$ New Zealand Journal of Psychiatry, 52(6), 542-551. https://doi.org/10.1177/0004867417714337

Center for Research on the Epidemiology of Disasters. (2018). Executive Summary. https://reliefweb.int/sites/reliefweb.int/files/resources/CREDNaturalDisaster2018 .pdf

Cisin, I. H., \& Clark, W. B. (1962). The methodological challenge of disaster research. In G. Baker \& D. Chapman (Eds.), Man and Society in Disaster (pp. 23-54). New York: Basic Books.

Crawford, P. A., Roberts, S. K., \& Zygouris-Coe, V. (2019). Addressing 21st-century crises through children's literature: picturebooks as partners for teacher educators. Journal of Early Childhood Teacher Education, 40(1), 44-56. https://doi.org/10.1080/10901027.2019.1570401 
Creswell, J. W. (2007). Qualitative Inquiry and Research Design: Choosing among Five Approaches (2nd ed.). Thousand Oaks, CA: Sage Publication.

Dinkmeyer, D. C., \& Dreikurs, R. (1979). Encouraging Children to Learn: The Encouragement Process. Massachusetts: Dutton Adult.

Fothergill, A. (2017). Children, Youth, and Disaster. In Oxford Research Encyclopedia of Natural Hazard Science. Oxford University Press.

https://doi.org/10.1093/acrefore/9780199389407.013.23

Global Facility for Disaster Reduction and Recovery. (2020). Indonesia. Retrieved from https://www.gfdrr.org/en/indonesia

Grace, C., \& Shores, E. (2010). After the Crisis: Using Storybooks to Help Children Cope. Lewisville, NC: Gryphon House.

Greenberg, N., Carr, J. A., \& Summers, C. H. (2002). Ethological Causes and Consequences of the Stress Response. Integrative \& Comparative Biology. http://trace.tennessee.edu/utk_ecolpubs/6

Hsiao, C.-Y., \& Chang, Y.-M. (2015). A Study of the Use of Picture Books by Preschool Educators in Outlying Islands of Taiwan. International Education Studies, 9(1), 1. https:// doi.org/10.5539/ies.v9n1p1

Hsiao, C.-Y., \& Shih, P.-Y. (2016). Exploring the effectiveness of picture books for teaching young children the concepts of environmental protection. International Research in Geographical and Environmental Education, 25(1), 36-49. https://doi.org/10.1080/10382046.2015.1106203

IFRC. (2020). What is Disaster. Https://Www.Ifrc.Org/En/What-We-Do/DisasterManagement/about-Disasters/What-Is-a-Disaster/.

International Insurance Institute. (2020). Facts + Statistics: Global catastrophes. https://www.google.com/search?client=safariErls=en $\mathcal{E} q=$ International+Insurance+Institute. $+(2020) .+$ Facts $+\% 2 B+$ Statistics: + Global+catastrophes $\mathcal{E} i e=U T F-8 \mathcal{E} 0 e=U T F-8$

Lacina, J., Bauml, M., \& Taylor, E. R. (2016). Promoting Resilience Through Read-Alouds. YC Young Children, 71(2), 16-21. www.jstor.org/stable/ycyoungchildren.71.2.16

Masten, A. S., \& Shaffer, A. (2006). How Families Matter in Child Development: Reflections from Research on Risk and Resilience. In Families Count (pp. 5-25). https://doi.org/10.1017/CBO9780511616259.002

Mcfarlane, A. C., Norris, F. H., Galea, S., Friedman, M. J., \& Watson, P. J. (2006). Definitions and Concepts in Disaster Research. In F.H. Norris, S. Galea, M.J. Friedman, \& P.J. Watson (Eds.), Methods of Disaster Mental Health Research (pp. 3-19). New York: The Guilford Press.

Mustika Sari, I. T., Toha, H., \& Nurani, Y. (2018). Improving Early Childhood Prosocial Behavior through Activity Storytelling with Puppets. Jurnal Obsesi : Jurnal Pendidikan Anak Usia Dini, 2(2), 155. https:/ / doi.org/10.31004/obsesi.v2i2.75

Norris, F. H., Friedman, M. J., Watson, P. J., Byrne, C. M., Diaz, E., \& Kaniasty, K. (2002). 60,000 Disaster Victims Speak: Part I. An Empirical Review of the Empirical Literature, 1981-2001. Psychiatry: Interpersonal and Biological Processes, 65(3), 207-239. https:/ / doi.org/10.1521/psyc.65.3.207.20173

Oliver, J. (1980). Response to disaster. Centre for Disaster Studies, James Cook University of North Queensland.

Osofsky, J. D., \& Reuther, E. T. (2013). Young children and disasters: lessons learned about resilience and recovery. Zero to Three, 34(2), 46-54.

Peek, L. (2008). Children and Disasters: Understanding Vulnerability, Developing Capacities, and Promoting Resilience-An Introduction. In Children, Youth and Environments (Vol. 18, Issue 1). http:/ / www.colorado.edu/journals/cye.

Pusat Kurikulum dan Perbukuan. (2018). Panduan Pemilihan Buku Nonteks Pelajaran. Kementerian Pendidikan dan Kebudayaan. 
http://repositori.kemdikbud.go.id/10407/1/Panduan\%20Pemilihan \%20Buku\%20N onteks\% 20Pelajaran.pdf

Putri Febriyanti. (2015). Aku Tahu Gempa Bumi. PT. Srikandi Empat Widya Utama (SEWU).

Raynaudo, G., \& Peralta, O. (2019). Children learning a concept with a book and an e-book: a comparison with matched instruction. European Journal of Psychology of Education, 34(1), 87-99. https:// doi.org/10.1007/s10212-018-0370-4

Ronan, K. R., \& Johnston, D. M. (2005). Promoting Community Resilience in Disasters. Springer US. https://doi.org/10.1007/b102725

San Agustin, M., Ramos-Bonoan, C., Lorenzana, R., Klass, P., \& Needlman, R. (2019). Picture Books and Reading Aloud to Support Children after a Natural Disaster: An Exploratory Study. International Journal of Emergency Mental Health and Human Resilience, 21(1), 1-6.

Scott, B. G., Lapré, G. E., Marsee, M. A., \& Weems, C. F. (2014). Aggressive Behavior and Its Associations With Posttraumatic Stress and Academic Achievement Following a Natural Disaster. Journal of Clinical Child \& Adolescent Psychology, 43(1), 43-50. https://doi.org/10.1080/15374416.2013.807733

Shultz, J. M., Espinola, M., \& Rechkemmer, A. (2017). Prevention of Disaster Impact and Outcome Cascades Environmentally and Climate Change Induced Forced Migration View project Global Environmental Governance View project. In Cambridge Handbook of International Prevention Science, Chapter: 21, Publisher: Cambridge University Press (pp. 492-519). Cambridge University Press. https://www.researchgate.net/publication/311767512

Simcock, G., \& DeLoache, J. (2006). Get the picture? The effects of iconicity on toddlers' reenactment from picture books. Developmental Psychology, 42(6), 1352-1357. https://doi.org/10.1037/0012-1649.42.6.1352

Sjoberg, G. (1962). Disasters and social change. In In G. Baker \& D. Chapman (Ed.), Man and society in disaster ( (pp. 356-384). New York: Basic Books.

Strouse, G. A., Nyhout, A., \& Ganea, P. A. (2018). The Role of Book Features in Young Children's Transfer of Information from Picture Books to Real-World Contexts. Frontiers in Psychology, 9. https:// doi.org/10.3389/fpsyg.2018.00050

Susman, P., \& O'keefe, P. (1983). Global disasters: A radical interpretation. In Interpretation of calamity from the viewpoint of human ecology (pp. 263-283). Allen \& Unwin Inc. https://www.researchgate.net/publication/279556375

UNDP. (2020). One of the world's most disaster-prone countries, Indonesia prepares school for tsunamis. Https://Www.Id.Undp.Org/Content/Indonesia/En/Home/Presscenter/Articles/ 2 018/One-of-the-World-s-Most-Disaster-Prone-Countries--Indonesia-Prep.Html. 